\title{
A comparison of cathodes for zero gap alkaline water electrolysers for hydrogen production
}

\author{
Derek Pletcher ${ }^{a}$, Xiaohong $\mathrm{Li}^{b, *}$, Shaopeng Wang ${ }^{b}$ \\ a School of Chemistry, University of Southampton, Highfield, University Road, Southampton SO17 1BJ, United Kingdom \\ ${ }^{\mathrm{b}}$ School of Engineering Sciences, University of Southampton, Highfield, University Road, Southampton SO17 1BJ, United Kingdom
}

\section{A R T I C L E I N F O}

Article history:

Received 22 September 2011

Received in revised form

2 February 2012

Accepted 2 February 2012

Available online $\mathrm{xxx}$

\section{Keywords:}

Cathode electrocatalysts

Alkaline water electrolysers

Zero gap membrane cells

Hydrogen production

\begin{abstract}
A B S T R A C T
Selected coatings on nickel or stainless steel micromeshes have been examined as electrocatalysts for hydrogen evolution in conditions mimicking those found in zero gap alkaline water electrolysers. Voltammetry in $4 \mathrm{M} \mathrm{NaOH}$ at a temperature of $333 \mathrm{~K}$, shows that $\mathrm{Pt}, \mathrm{NiMo}$ and $\mathrm{RuO}_{2}$ are the coatings of choice giving a superior performance particularly at higher current densities. NiMo and $\mathrm{RuO}_{2}$ coatings also give stable performance during a 10 day electrolysis in a laboratory, zero gap, alkaline water electrolysis cell with a hydroxide conducting membrane; when combined with a $\mathrm{NiFe}(\mathrm{OH})_{2}$ coated anode, a current density of $1 \mathrm{~A} \mathrm{~cm}^{-2}$ is achieved with a cell voltage of $\sim 2.1 \mathrm{~V}$. Pt catalyses $\mathrm{H}_{2}$ evolution efficiently at short times of electrolysis but cells with a Pt cathode show an increase in cell voltage from $2.05 \mathrm{~V}$ to $2.23 \mathrm{~V}$ during the first two days of operation.

Crown Copyright ๔ 2012, Hydrogen Energy Publications, LLC. Published by Elsevier Ltd. All
\end{abstract} rights reserved.

\section{Introduction}

With limited resources of C-based fuels, hydrogen is expected to provide an essential component to the solution of our needs for a sustainable fuel for our future transport requirements and also an approach to large-scale storage of energy. Presently, $95 \%$ of the world's hydrogen is produced by the reformation of hydrocarbons and this is an energy intensive process consuming hydrocarbons and also leading to carbon dioxide. In contrast, water electrolysis provides a clean route to hydrogen without the consumption of fossil fuel or the emission of carbon dioxide. If the electricity comes from renewable energy sources, water electrolysis becomes a truly green technology [1,2]. In consequence, there is presently much interest in new hydrogen technology that is cheaper and consumes less energy.

Existing water electrolysis plants are usually based on cells with an aqueous alkaline electrolyte and a porous separator.
The maximum current density is typically $\sim 0.25 \mathrm{~A} \mathrm{~cm}^{-2}$ and its energy efficiency is typically only $\sim 60 \%$. These shortcomings led to the development of solid polymer electrolyte (SPE) water electrolysers [3,4]. Acidic SPE electrolysers have a substantial improvement of conversion efficiency and are commercially available in small units. Until now, however, this technology cannot be regarded as low cost because of its heavy dependence on precious metals as catalysts and also using expensive Nafion ${ }^{\circledR}$ membranes.

Alkaline SPE water electrolysers based on a nonperfluorinated, hydroxide ion permeable membrane and non-precious metal catalysts for both oxygen and hydrogen evolution should lead to substantial reductions in the investment cost of cells and also the possibility of lower energy consumption [1]. Overall there would be a significant reduction in the cost of hydrogen production. In our previous paper, we have studied a number of nickel based materials as potential oxygen evolution catalysts under conditions close to

\footnotetext{
* Corresponding author. Tel.: +44 2380594905; fax: +44 2380597051.

E-mail address: Xh.Li@soton.ac.uk (X. Li).
}

0360-3199/\$ - see front matter Crown Copyright @ 2012, Hydrogen Energy Publications, LLC. Published by Elsevier Ltd. All rights reserved. doi:10.1016/j.ijhydene.2012.02.013 
those in a zero gap alkaline water electrolyser [5]. Several nickel based mixed oxides/hydroxides have been identified as suitable anode catalysts for oxygen evolution.

In this paper, we report studies on cathode catalysts for hydrogen evolution suitable for zero gap alkaline water electrolysers. Hydrogen evolution is probably the most extensively studied electrode reaction [6-9]. The literature, however, seldom addresses the conditions likely to be found in modern, alkaline water electrolysers, namely current densities in the range $0.5-2.0 \mathrm{~A} \mathrm{~cm}^{-2}$ and temperatures in the range $323-363 \mathrm{~K}$. We have sought to compare a number of promising candidate cathode materials largely selected from knowledge of cathode performance in chlor alkali cells. The materials selected for study were platinum [9-14] (for comparison), ruthenium dioxide [15-24], nickel and nickel alloys [7,25-44] although cost considerations would lead to a preference for non-precious metal materials in commercial water electrolysis cells.

\section{Experimental}

The substrates for all the coatings were either $\mathrm{Ni}$ mesh (DeXmet Corporation, $4 \mathrm{Ni}$ 6-040, 0.004" nominal thickness, $0.006^{\prime \prime}$ strand width, $0.040^{\prime \prime}$ long diagonal of the diamond) or stainless steel mesh (DeXmet Corporation, 4SS 5-050, 0.004" nominal thickness, $0.005^{\prime \prime}$ strand width, $0.050^{\prime \prime}$ long diagonal of the diamond); SEM images of these meshes are shown in Fig. 1. The Pt was deposited onto stainless steel and $\mathrm{Ni}, \mathrm{NiAl}$ and NiMo coatings onto Ni mesh using magnetron sputtering by Teer Coatings Ltd. using conditions developed in order to produce high surface area coatings [45]. The coatings were $\sim 1.5 \mu \mathrm{m}$ thick and SEM images are shown in Fig. 1(c)-(f). The $\mathrm{Ni} / \mathrm{S}$ coating was cathodically deposited onto $\mathrm{Ni}$ mesh at $10 \mathrm{~mA} \mathrm{~cm}^{-2}$ at $298 \mathrm{~K}$ for $30 \mathrm{~min}$ in an electrolyte containing $200 \mathrm{gL}^{-1} \mathrm{NiSO}_{4} \cdot 7 \mathrm{H}_{2} \mathrm{O}, 20 \mathrm{gL}^{-1} \mathrm{NaCl}, 40 \mathrm{gL}^{-1} \mathrm{H}_{3} \mathrm{BO}_{3}$, and $100 \mathrm{~g} \mathrm{~L}^{-1}$ thiourea as the source of sulphur [46], see Fig. 1(g). The $\mathrm{RuO}_{2}$ coating was deposited using thermal decomposition of a $\mathrm{Ru}$ (III) solution onto the Ni mesh by Permascand $\mathrm{AB}$, Sweden, see Fig. 1(h).

Slow scan voltammetry into the potential region for $\mathrm{H}_{2}$ evolution has been used to compare the catalytic activities of the coating materials. Electrochemical measurements were carried out using an Autolab potentiostat/galvanostat PGSTAT30 in a small-undivided beaker cell (volume $20 \mathrm{~cm}^{3}$ ) equipped with a water jacket connected to a Camlab W14 water thermostat. A small piece of coated mesh, a large area platinum gauze and a mercury/mercury oxide electrode ( $\mathrm{Hg} /$ $\mathrm{HgO}$ in $4 \mathrm{M} \mathrm{NaOH}$ ) were used as working, counter and reference electrodes, respectively. The reference electrode was always at the same temperature as the working electrode. In order to minimise IR drop and hence make more reliable comparison of materials at the high current densities of interest for water electrolysers, the measurements were carried out with small area cathodes. The coated meshes were masked with an insulating polyimide tape, leaving a small area, $0.03 \mathrm{~cm}^{2}$, on one face of the mesh exposed to the solution. The working electrode was placed vertically and parallel to the counter electrode. Hydrogen bubbles leaving the cathodes surface are clearly visible and consequent oscillations in the current are always observed. Even so, while this approach will not totally eliminate the uncompensated IR drop, it appears to allow the recording of reliable comparative data. Prior to testing, all of the coating materials were cleaned by soaking in first acetone and then water, each for $15 \mathrm{~min}$. The catalytic activity of various coating materials for hydrogen evolution was assessed by recording voltammograms at coating electrodes at a temperature of $333 \mathrm{~K}$ in $4 \mathrm{M} \mathrm{NaOH}$ using a potential scan rate of $1 \mathrm{mV} \mathrm{s}^{-1}$. Throughout the paper, current densities were based on the geometric area of the mesh cathodes used in the experiment.

The electrolyses were carried out at a temperature of $333 \mathrm{~K}$ using a zero gap cell with a $160 \mu \mathrm{m}$ thick, hydroxide ion conducting membrane under development by ITM Power plc, UK. The cell was assembled with the two mesh electrodes (each geometric area, $9 \mathrm{~cm}^{2}$ ) pressed up against the membrane and $4 \mathrm{M} \mathrm{NaOH}$ flowed down the rear of the meshes at a flow rate of $15 \mathrm{~cm}^{3} \mathrm{~min}^{-1}$ to prevent gas accumulation. The anode was the fine stainless steel mesh coated with a $\mathrm{Ni} / \mathrm{Fe}$ hydroxide layer by cathodic electrodeposition [5] and the cathodes were the various coated materials. Prior to recording the cell current versus cell potential curves, electrolysis with a current density of $1 \mathrm{~A} \mathrm{~cm}^{-2}$ for $1 \mathrm{~h}$ was carried out in order for the cell components to approach their steady state performance. The longevity tests were carried out in the same cell under constant electrolysis at a current density of $1 \mathrm{~A} \mathrm{~cm}^{-2}$ at $333 \mathrm{~K}$ and ambient pressure.

The surface morphology and composition of the samples were characterized using a JSM-6500F scanning electron microscope (SEM) equipped with energy dispersive X-ray (EDX) microanalysis (Oxford Inca 300) and operated at an accelerating voltage of $15 \mathrm{kV}$.

\section{Results and discussion}

High magnification SEM images of the coatings are reported in Fig. 1. All the coatings can be seen to be uniform. The coatings prepared by magnetron sputtering all have a reflecting metallic appearance by visual observation and exhibit excellent adhesion when tested with sticky tape. The Pt coating, Fig. 1(c), can be seen to have a structure consisting of tightly packed centres with dimensions below $100 \mathrm{~nm}$ and these centres are themselves made up of smaller growths. When studied by cyclic voltammetry in $1 \mathrm{M} \mathrm{H}_{2} \mathrm{SO}_{4}$, the response shows clean peaks for the PtO/Pt couple and $\mathrm{H}$ adsorption/ desorption $[47,48]$. Calculation of the charge under the $\mathrm{H}$ adsorption peaks indicates that the surface has a roughness factor of 244; this is a high value comparable to that for Pt blacks. The nickel and nickel alloy coatings also all consist of tightly packed centres made up of smaller growths and the dimensions of the centres increase along the series $\mathrm{Pt}<\mathrm{Ni}<\mathrm{NiMo}<\mathrm{NiAl}$. As a result, the NiAl has very much the appearance of a 'standard cauliflower' structure, common in metal deposits. All may be considered high surface area deposits. Indeed, the roughness factor for the nickel as estimated from the charge under the $\mathrm{Ni}(\mathrm{OH})_{2} / \mathrm{NiOOH}$ peak on a cyclic voltammogram in $1 \mathrm{M} \mathrm{NaOH}[49]$ is 240. EDX analysis gives a Mo and $\mathrm{Al}$ content of the alloys of $\sim 20$ at. \%. The Ni/S coating prepared by electrodeposition is also bright and 

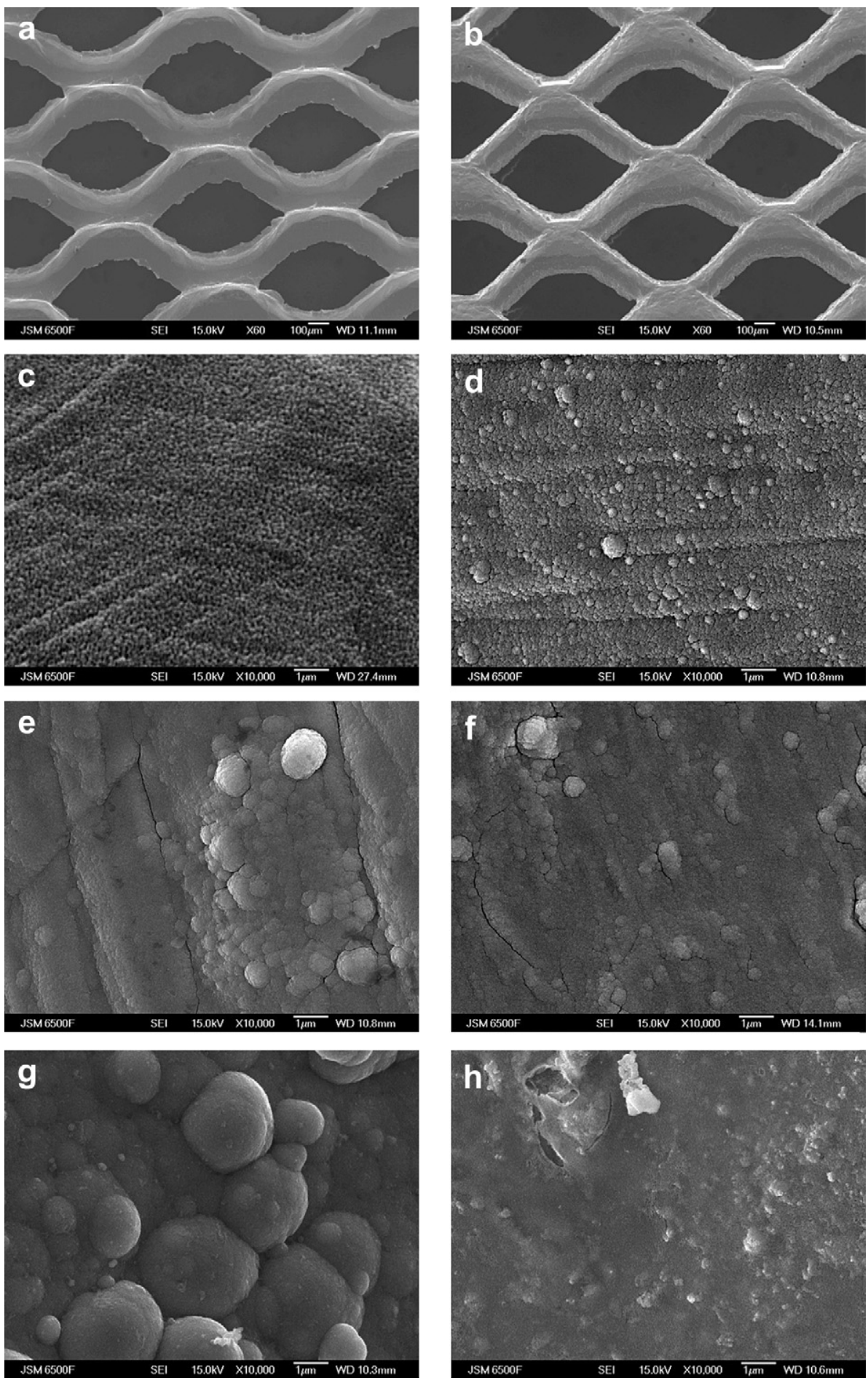

Fig. 1 - Low resolution SEM images of (a) Ni micromesh and (b) stainless steel micromesh, and high-resolution SEM images of the various coatings: (c) Pt; (d) Ni; (e) NiAl; (f) NiMo; (g) NiS; (h) $\mathrm{RuO}_{2}$.

appears uniform to the eye. The high magnification image also shows a 'cauliflower' structure with centres up to a few microns. At a lower magnification, the layer can be seen to be cracked but otherwise uniform. By eye, the $\mathrm{RuO}_{2}$ coating is black and compact and the high magnification SEM image reveals little about the layer structure. On a lower magnification, the layer again looks uniform but some cracks typical of thermally produced layers can be observed.
The catalytic activities of the cathodes were compared by recording voltammograms in $4 \mathrm{M} \mathrm{NaOH}$ as the electrolyte and at a temperature of $333 \mathrm{~K}$. It was recognised that at the current densities of interest for water electrolysers (up to $2 \mathrm{~A} \mathrm{~cm}^{-2}$ ), IR distortion of the voltammograms would be inevitable particularly with the high volume of gas being evolved. In this work, data are always presented as potentials and we are reluctant to discuss the results in terms of overpotentials or more

Please cite this article in press as: Pletcher D, et al., A comparison of cathodes for zero gap alkaline water electrolysers for hydrogen production, International Journal of Hydrogen Energy (2012), doi:10.1016/j.ijhydene.2012.02.013 

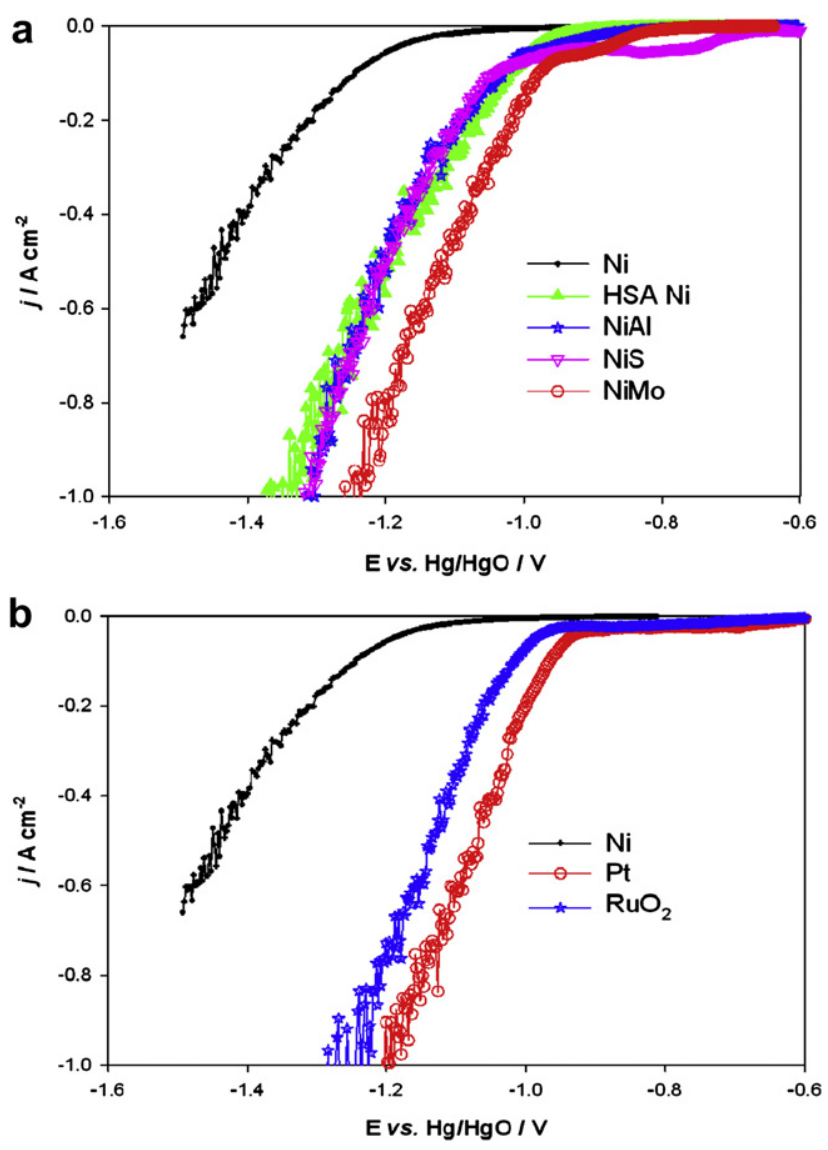

Fig. 2 - Steady state polarization curves recorded for hydrogen evolution at various coating materials in $4 \mathrm{M}$ $\mathrm{NaOH}$ at $333 \mathrm{~K}$ with a potential sweep rate of $1 \mathrm{mV} \mathrm{s}^{-1}$ : (a) Ni mesh, high area Ni, NiAl, NiS and NiMo coatings; (b) Ni mesh, $\mathrm{Pt}$ and $\mathrm{RuO}_{2}$ coatings.

fundamental factors because of the inclusion of IR drops in all the measured potentials. This IR distortion of the data was minimised by using a small area cathode and positioning the electrode so that the hydrogen gas left the working-counter electrode gap as rapidly as possible. With these precautions, it was believed that the comparison of materials would be sound.

Fig. 2 shows voltammograms recorded at $1 \mathrm{mV} \mathrm{s}^{-1}$ and all show increasing current densities for hydrogen evolution negative to $-0.95 \mathrm{~V}$ vs. the $\mathrm{Hg} / \mathrm{HgO}$ reference electrode. Data from the responses are also summarised in Table 1. It can be seen that all the coatings studied lead to hydrogen evolution at a substantially less negative potential than uncoated $\mathrm{Ni}$ mesh. Fig. 2(a) reports the responses for the Ni based materials and it can be seen that the high surface area $\mathrm{Ni}$, the $\mathrm{NiAl}$ and $\mathrm{Ni} / \mathrm{S}$ give very similar voltammograms, The aluminium and sulphur are probably dissolving by corrosion and anodic dissolution (to give $\mathrm{Al}(\mathrm{III})$ in solution or surface film) and cathodic reduction (to give sulphide in solution) to give more porous and higher area layers than the as-prepared coatings. The presence of molybdenum in the nickel alloy leads to a significant further improvement in performance. It appears that Mo acts as a genuine catalyst as well as increasing the active areas [1]. Variation of the Mo content between 20 and 50 at. \% did not lead to discernable changes to the electrocatalytic activity. Fig. 2(b) compares the voltammograms for Pt and $\mathrm{RuO}_{2}$ with uncoated Ni. The performance of the $\mathrm{RuO}_{2}$ is very comparable to that of the NiMo. In this short timescale experiment, however, Pt shows the best performance.

The data in Table 1 shows a further interesting feature. For a current density of $0.1 \mathrm{~A} \mathrm{~cm}^{-2}$, the potentials of all the coatings fall in the narrow range, $-0.97 \mathrm{~V}$ to $-1.04 \mathrm{~V}$, close to the equilibrium potential for the $\mathrm{H}_{2} \mathrm{O} / \mathrm{H}_{2}$ couple estimated as $-0.93 \mathrm{~V}$ vs. the $\mathrm{Hg} / \mathrm{HgO}$ reference electrode [50] in the experimental conditions. But when the current density had the higher value of $0.5 \mathrm{~A} \mathrm{~cm}^{-2}$, the coatings showed a greater divulgence in performance and $\mathrm{Pt}, \mathrm{RuO}_{2}$ and NiMo appear to be superior. This division in performance becomes more marked if the voltammograms were continued to even higher current densities.

Current density vs. cell potential were recorded for each of the coatings in a zero gap electrolysis cell where two mesh electrodes were pressed up against a hydroxide conducting membrane and each was fed with $4 \mathrm{M} \mathrm{NaOH}$ at $333 \mathrm{~K}$, see Fig. 3. Data taken from these responses are also reported in Table 1. In all cases the anode was a $\mathrm{NiFe}(\mathrm{OH})_{2}$ coating on stainless steel mesh as described in an earlier paper [5] and

Table 1 - (a) Potentials from voltammograms for the evolution of hydrogen at a current density of 0.1 and $0.5 \mathrm{~A} \mathrm{~cm}{ }^{-2}$. (b) Cell potential for a zero gap water electrolysis cell at a current density of $0.1,0.5$ and $1.0 \mathrm{~A} \mathrm{~cm}^{-2}$. (c) Cell potential for a zero gap water electrolysis cell after electrolysis at a current density of $1.0 \mathrm{~A} \mathrm{~cm}^{-2}$ for 10 days (* except for uncoated Ni and high area Ni when the electrolysis were discontinued after 2 days). $4 \mathrm{M} \mathrm{NaOH} .333 \mathrm{~K}$.

\begin{tabular}{|c|c|c|c|c|c|c|}
\hline \multirow[t]{2}{*}{ Cathode } & \multicolumn{2}{|c|}{ (a)E vs. $\mathrm{Hg} / \mathrm{HgO} / \mathrm{V}$} & \multicolumn{3}{|c|}{ (b) $E_{\text {cell }} / \mathrm{V}$} & \multirow{2}{*}{$\begin{array}{l}\text { (c) } E_{\text {cell }} / V \text { after } 10 \text { days } \\
\text { electrolysis at } 1 \mathrm{~A} \mathrm{~cm}^{-2}\end{array}$} \\
\hline & $0.1 \mathrm{~A} \mathrm{~cm}^{-2}$ & $0.5 \mathrm{~A} \mathrm{~cm}^{-2}$ & $0.1 \mathrm{~A} \mathrm{~cm}^{-2}$ & $0.5 \mathrm{~A} \mathrm{~cm}^{-2}$ & $1.0 \mathrm{~A} \mathrm{~cm}^{-2}$ & \\
\hline Uncoated $\mathrm{Ni}$ & -1.25 & -1.44 & 2.00 & 2.23 & 2.42 & $2.48^{*}$ \\
\hline High area Ni & -1.02 & -1.19 & 1.83 & 2.07 & 2.28 & $2.37^{*}$ \\
\hline $\mathrm{NiAl}$ & -1.03 & -1.20 & 1.83 & 2.06 & 2.24 & 2.33 \\
\hline $\mathrm{NiS}$ & -1.04 & -1.20 & 1.75 & 1.95 & 2.16 & 2.32 \\
\hline NiMo & -0.98 & -1.12 & 1.71 & 1.90 & 2.04 & 2.14 \\
\hline $\mathrm{RuO}_{2}$ & -1.02 & -1.14 & 1.67 & 1.86 & 2.02 & 2.06 \\
\hline Pt & -0.97 & -1.07 & 1.61 & 1.80 & 2.00 & 2.23 \\
\hline
\end{tabular}




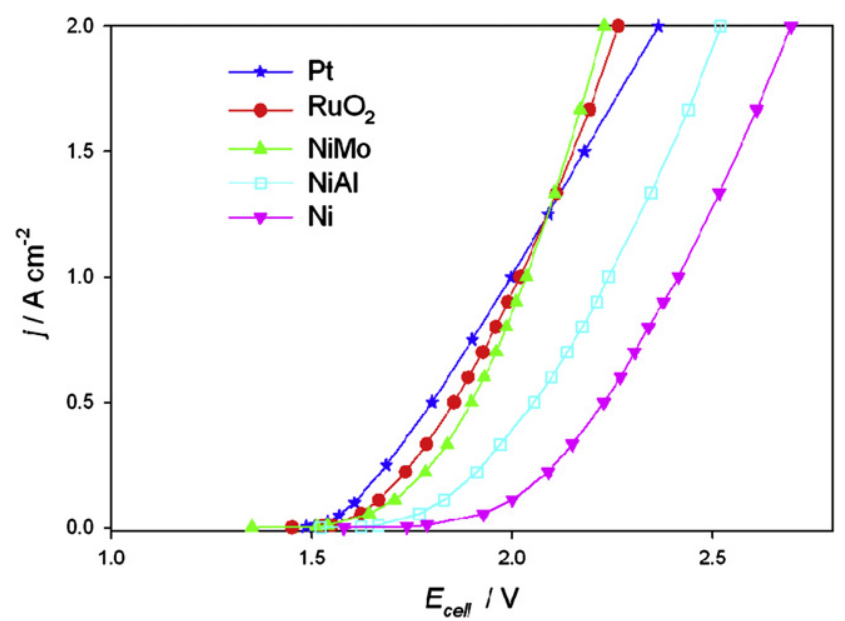

Fig. 3 - Cell current vs. cell voltage plots for the zero gap, alkaline water electrolyser with various coating materials as cathode and NiFe hydroxide as anode pressed up against the hydroxide ion exchange membrane in $4 \mathrm{M}$ $\mathrm{NaOH}$ at $333 \mathrm{~K}$ (electrode areas $9 \mathrm{~cm}^{2}$ ).

the cell was run at $1 \mathrm{~A} \mathrm{~cm}^{-2}$ for $1 \mathrm{~h}$ prior to recording the response in order to stabilise the cell components. It can be seen that with this cell configuration, water electrolysis commences with a cell voltage close to $1.5 \mathrm{~V}$ and it is possible to achieve very high current densities, at least $2 \mathrm{~A} \mathrm{~cm}^{-2}$ with moderate cell voltages, despite a probable significant contribution from IR drop. Again the best catalysts appear to be Pt, $\mathrm{RuO}_{2}$ and NiMo when the cell voltages for current densities of $0.1,0.5$ and $1 \mathrm{~A} \mathrm{~cm}^{-2}$ are $\sim 1.7 \mathrm{~V},<1.9 \mathrm{~V}$ and $<2.1 \mathrm{~V}$ respectively, see data in Table 1 . It can also be seen that the Pt coating appears superior below $1 \mathrm{~A} \mathrm{~cm}^{-2}$ but loses its advantage at even higher current densities.

The same cell was used to examine the longer term performance of the cells and the cell voltages were monitored during continuous electrolyses carried out for a period of 10 days with a current density of $1 \mathrm{~A} \mathrm{~cm}^{-2}$; in fact these data were recorded following the recording of the cell current vs. cell voltage responses discussed above. Fig. 4 shows the results for the three preferred electrocatalysts while cell voltages for all the coatings are reported in Table 1. At least some of the small variations in cell voltage arise as a result of periodic maintenance of the system, e.g. addition of water and overnight, small changes to temperatures. Clearly, however, the cell with the Pt cathode catalyst showed an increase in cell voltage from an initial value of $2.07 \mathrm{~V}$ to a steady state value of $2.23 \mathrm{~V}$ during the first two days. After the 10 day electrolysis with this cell, the operating current was stepped between $1 \mathrm{~A} \mathrm{~cm}^{-2}$ and zero at 4 hour intervals; on recommencing the electrolysis, the cell voltage always returned immediately to 2.23 V. The Pt surface is undergoing a rather rapid and irreversible decay in performance and this probably results from the adsorption of trace organics in the system, e.g. from the membrane. The cell with the NiMo catalysed cathode also showed a smaller but rapid increase voltage, settling down at $2.14 \mathrm{~V}$ while the cell with the $\mathrm{RuO}_{2}$ catalysed cathode

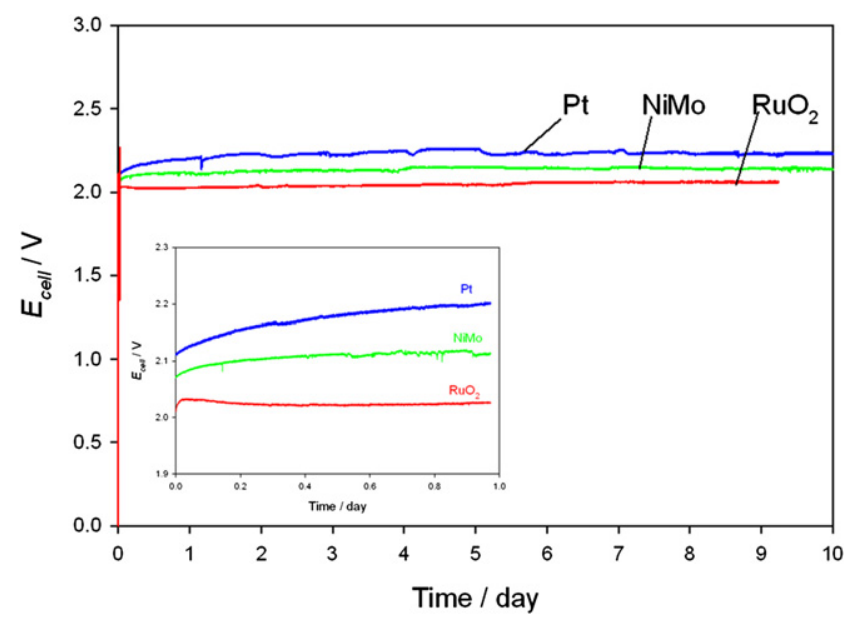

Fig. 4 - Cell voltage for the zero gap, alkaline water electrolyser during 10 days of electrolysis with the three preferred cathode coatings. The inset shows an expansion of the behaviour during the first day.

maintained a steady voltage of $2.06 \mathrm{~V}$. For comparison, it should be noted that the cell with an uncoated Ni cathode had a cell voltage of $2.48 \mathrm{~V}$. As a further demonstration of the stability of the cell performances, the cell current vs. cell
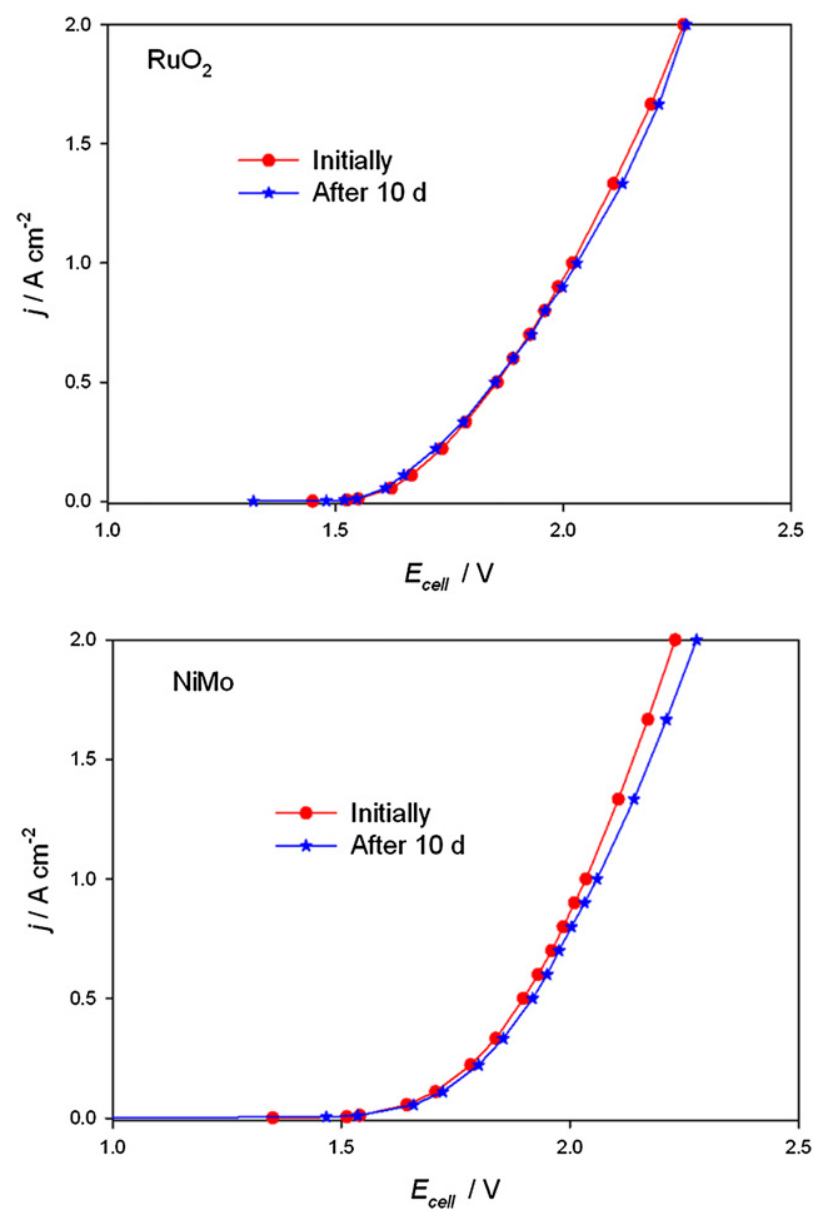

Fig. 5 - Cell current vs. cell voltage curves recorded before and after the 10 days electrolysis with $\mathrm{RuO}_{2}$ and NiMo coatings as cathode. 
voltage responses were recorded at the end of the 10-day electrolysis. The results for $\mathrm{RuO}_{2}$ and NiMo are shown in Fig. 5 where it can be seen that the change is very small.

\section{Conclusions}

Throughout this paper, the approach has been to compare practical electrocatalysts for the cathode reaction in zero gap alkaline water electrolysers. It is clear that both $\mathrm{RuO}_{2}$ and NiMo are stable coatings that can support very high current densities in alkaline media. Indeed, they seem to be very promising materials for zero gap alkaline water electrolysers, a technology likely to become more important in the near future.

\section{Acknowledgement}

The authors would like to thank Kevin Cooke and Xiaoling Zhang of Teer Coatings Ltd Miba Coating Group and Erik Zimmerman of Permascand $A B$ for the supply of coated materials and ITM Power plc, UK for the supply of the membrane. The authors also acknowledge the financial support provided by the Technology Strategy Board. Shaopeng Wang acknowledges Northwestern Polytechnical University for supporting his study at University of Southampton.

\section{R E F E R E N C E S}

[1] Li X, Pletcher D. Prospects for alkaline, zero gap water electrolysers for hydrogen production. Int J Hydrogen Energy 2011;36:15089-104.

[2] Zeng K, Zhang D. Recent progress in alkaline water electrolysis for hydrogen production and applications. Prog Energy Combust Sci 2010;36:307-26.

[3] La Conti AB, Swette L. In: Vielstich W, Lamm A, Gasteiger HA, editors. Special applications using PEM-technology. Handbook of fuel cells, vol. 3. Wiley; 2003. p. 745-61. Part 3.

[4] Millet P, Mbemba N, Grigoriev SA, Fateev VN, Aukauloo A, Etievant C. Electrochemical performances of PEM water electrolysis cells and perspectives. Int J Hydrogen Energy 2011;36:4134-42.

[5] Li X, Walsh FC, Pletcher D. Nickel based electrocatalysts for oxygen evolution in high current density alkaline water electrolysers. Phys Chem Chem Phys 2011;13:1162-7.

[6] Appleby AJ, Kita H, Chemla M, Bronoel G. In: Bard AJ, editor. Hydrogen. Encyclopedia of electrochemistry of the elements, vol. IXa. Marcel Dekker; 1982. p. 383-597.

[7] Trasatti S. In: Gerischer H, Tobias CW, editors. Progress in cathode activation. Advances in electrochemical science and engineering, vol. 2. VCH; 1992. p. 1-85.

[8] Breiter MW. In: Vielstich W, Gasteiger HA, Lamm A, editors. The hydrogen oxidation/evolution reaction. Handbook of fuel cells, vol. 2. Wiley; 2003. p. 361-80.

[9] Couper AM, Pletcher D, Walsh FC. Electrode materials for electrosynthesis. Chem Rev 1990;90:837-65.

[10] Vielstich W, Gasteiger HA, Lamm A, editors. Handbook of fuel cells, vols. 1-5. Wiley; 2003.
[11] Cairns JF, Couper AM, Denton DA. In: Wall K, editor. Electrode coatings for membrane cells. Modern chlor-alkali technology, vol. 3. SCI/Horwood; 1986. p. 293-309.

[12] Groves DE. In: Wall K, editor. Precious-metal activated cathodes for chlor-alkali cells. Modern chlor-alkali technology, vol. 3. SCI/Horwood; 1986. p. 250-62.

[13] Cameron DS, Phillips RL, Willis PM. In: Prout NM, Moorhouse JS, editors. Poison tolerant platinum catalysed cathodes for membrane cells. Modern chlor-alkali technology, vol. 4. SCI/Elsevier Applied Science; 1990. p. 95-107.

[14] Cairns JF, Cook MR, Hayes PM, Hodgson DR, Izzard PA, Mockford MJ, et al. Advances in ICI's activated cathode technology for chlor-alkali production. Proc Electrochem Soc 1998;98:289-96.

[15] Trasatti S. In: Wellington TC, editor. Hydrogen evolution on oxide electrodes. Modern chlor-alkali technology, vol. 5. SCI/ Elsevier Applied Science; 1992. p. 281-94.

[16] Trasatti S. Interfacial electrochemistry of conductive oxides for electrolysis. In: Wieckowski A, editor. Interfacial electrochemistry - theory, experiment and applications. Marcel Dekker; 1999. p. 769-92.

[17] Burke LD, Naser NS. Metastability and electrocatalytic activity of ruthenium dioxide cathodes used in water electrolysis cells. J Appl Electrochem 2005;35:931-8.

[18] Spãtaru N, Le Helloco J-G, Durand R. A study of $\mathrm{RuO}_{2}$ as an electrocatalyst for hydrogen evolution in alkaline solution. J Appl Electrochem 1996;26:397-402.

[19] Iwakura C, Furukawa N, Tanaka M. Electrochemical preparation and characterisation of $\mathrm{Ni} /\left(\mathrm{Ni}+\mathrm{RuO}_{2}\right)$ composite coatings as an active cathode for hydrogen evolution. Electrochim Acta 1992;37:757-8.

[20] Iwakura C, Tanaka M, Nakamatsu S, Inoue H, Matsuoka M, Furukawa N. Electrochemical properties of $\mathrm{Ni} /\left(\mathrm{Ni}+\mathrm{RuO}_{2}\right)$ active cathodes for hydrogen evolution in chloralkali electrolysis. Electrochim Acta 1995;40:977-82.

[21] Tavares AC, Trasatti S. Ni+RuO 2 co-deposited electrodes for hydrogen evolution. Electrochim Acta 2000;45:4195-202.

[22] Vázquez-Gómez L, Cattarin S, Guerriero P, Musiani M. Preparation and electrochemical characterization of $\mathrm{Ni}+\mathrm{RuO}_{2}$ composite cathodes of large effective area. Electrochim Acta 2007;52:8055-63.

[23] Vázquez-Gómez L, Cattarin S, Guerriero P, Musiani M. Influence of deposition current density on the composition and properties of electrodeposited $\mathrm{Ni}+\mathrm{RuO}_{2}$ and $\mathrm{Ni}+\mathrm{IrO}_{2}$ composites. J Electroanal Chem 2009;634:42-8.

[24] Tsou YM. Reinforced composite-reductively deposited catalytic coating for hydrogen evolution. J Electroanal Chem 2001;498:223-7.

[25] Appleby AJ, Crepy G, Jacquelin J. High-efficiency water electrolysis in alkaline solution. Int J Hydrogen Energy 1978; 3:21-37.

[26] Danna PA, Woodard KE. In: Jackson C, editor. Olin membrane cell technology. Modern chlor-alkali technology, vol. 2. SCI/ Horwood; 1983. p. 121-31.

[27] Dworak R, Lohrberg K, Müller R. In: Wellington TC, editor. Lurgi's experience with steel and Raney-nickel as cathode material. Modern chlor-alkali technology, vol. 5. SCI/Elsevier Applied Science; 1992. p. 257-64.

[28] Brown DE, Fogarty PO, Mahmood MN, Turner AK. In: Jackson C, editor. The development of low overvoltage cathodes. Modern chlor-alkali technology, vol. 2. SCI/ Horwood; 1983. p. 233-45.

[29] Brown DE, Mahmood MN, Man MCM, Turner AK. Preparation and characterisation of low overvoltage transition-metal alloy electrocatalysts for hydrogen evolution in alkaline solutions. Electrochim Acta 1984;29:1551-6. 
[30] Endoh E, Otouma H, Morimoto T, Oda Y. New Raney-nickel composite-coated electrode for hydrogen evolution. Int $\mathrm{J}$ Hydrogen Energy 1987;12:473-9.

[31] Divisek J, Schmidt H, Mergel J. Novel diaphragms and electrode designs for electrolysis of water and alkali chloride. Chem Ing Tech 1980;52:465.

[32] Rausch S, Wendt H. Morphology and utilization of smooth hydrogen-evolving Raney nickel cathode coatings and porous sintered-nickel cathodes. J Electrochem Soc 1996;143:2852-62.

[33] Tanaka S, Hirose N, Tanaki T, Ogatab YH. Effect of Ni-Al precursor alloy on the catalytic activity for a Raney-Ni cathode. J. Electrochem Soc 2000;147:2242-5.

[34] Yoshida N, Morimoto T. A new low hydrogen overvoltage cathode for chloralkali electrolysis cell. Electrochim Acta 1994;39:1733-7.

[35] Shervedani RK, Lasia A. Study of the hydrogen evolution reaction on $\mathrm{Ni}-\mathrm{Mo}-\mathrm{P}$ electrodes in alkaline solutions. J Electrochem Soc 1998;145:2219-25.

[36] Han Q, Cui S, Pu N, Chen J, Liu K, Wei X. A study on pulse plating amorphous $\mathrm{Ni}-\mathrm{Mo}$ alloy coating used as HER cathode in alkaline medium. Int J Hydrogen Energy 2010;35:5194-201.

[37] Divisek J, Schmitz H, Balej J. Ni and Mo coatings as hydrogen cathodes. J Appl Electrochem 1989;19:519-30.

[38] Huot JY, Trudeau ML, Schulz R. Low hydrogen overpotential nanocrystalline Ni-Mo cathodes for alkaline water electrolysis. J Electrochem Soc 1991;138:1316-21.

[39] Rodríguez-Valdez LM, Estrada-Guel I, Almeraya-Calderón F, Neri-Flores MA, Martínez-Villafańne A, Martínez-Sánchez R. Electrochemical performance of hydrogen evolution reaction of Ni-Mo electrodes obtained by mechanical alloying. Int $\mathrm{J}$ Hydrogen Energy 2004;29:1141-5.
[40] Miousse D, Lasia A, Borck V. Hydrogen evolution on $\mathrm{Ni}-\mathrm{Al}-\mathrm{Mo}$ and $\mathrm{Ni}-\mathrm{Al}$ electrodes prepared by lowpressure plasma spraying. J Appl Electrochem 1995;25: 592-602.

[41] Schiller G, Henne R, Mohr P, Peinecke P. High performance electrodes for an advanced intermittently operated $10-\mathrm{kW}$ alkaline water electrolyzer. Int J Hydrogen Energy 1998;23: 761-5.

[42] Birry L, Lasia A. Studies of the hydrogen evolution reaction on Raney nickel-molybdenum electrodes. J Appl Electrochem 2004;34:735-49.

[43] Hu W, Cao X, Wang F, Zhang Y. A novel cathode for alkaline water electrolysis. Int J Hydrogen Energy 1997;22: 441-3.

[44] $\mathrm{Hu} \mathrm{W}$. Electrocatalytic properties of new electrocatalysts for hydrogen evolution in alkaline water electrolysis. Int J Hydrogen Energy 2000;25:111-8.

[45] Zhang X, Hampshire J, Cooke K. unpublished results.

[46] Vandenborre H, Vermeiren PH, Leysen R. Hydrogen evolution at nickel sulphide cathodes in alkaline medium. Electrochim Acta 1984;29:297-301.

[47] Bai L, Gao L, Conway BE. Problem of in situ real-area determination in evaluation ofperformance of rough or porous, gas-evolving electrocatalysts. J Chem Soc Faraday Trans 1993;89:235-42.

[48] Conway BE. Prog Surf Sci 1995;49:331-452.

[49] Fleischmann M, Korinek K, Pletcher D. J Electroanal Chem 1971;31:39-49.

[50] Ives DJG. Oxide, oxygen, and sulfide electrodes. In: Ives DJG, Janz GJ, editors. References electrodes. New York: Academic Press; 1961. p. 335-6. 